\title{
MONTAGE
}

\section{FREJ OG DEN STORE VANDSALAMANDER}

\author{
En metamorfisk montage
}

\section{ADAM VENG, MAGNUS JUHL OG CECILIE RUBOW}

ild under vand

du store kineser

du drage i skjul på jorden

klare vand

sigt barhed

stille i vandsøjlen står du

mellem urtid og demokrati

klar til at sigte og bide

drages

mod hun

og holder vejr

du haler hende ind

med krumme svirp,

der kammer over

som stopper gællerne

og kvæler

væksten

med væksten

med tekstens DNA

som du bider ind i muren af morgenrøde

om kolonien af unge aber,

der blev ved med at veje

og opveje

og måle

og opveje

og pladre til takkerne

og tankerne

og safterne

som ægget

med sin egen sfære

beskyttes

med bagben

i bløde triumfbuer

i bøjning af blad

her gælder det

som ung drage

at unddrage

det forplumrede

i denne underverden

de findes for lette,

eller fanger

du gamle drage i min rygsøjle

du nordiske

og jordiske

og vandiske

og formindske

kæmpe,

store,

vandsalamander

ild under vand 


\section{Artsambassadøren}

Den 24. november 2019 reciterede Frej Pries Schmedes „Ild under vand“ på ydre Østerbro til åbningen af Arternes Ambassade i København. Iklædt hvid skjorte og mørkegrøn blazer læste den 46-årige filminstruktør op med nerve. Han var netop blevet udnævnt som ambassadør for sin „elskede store vandsalamander“. ${ }^{1}$ Forsamlingen tog imod digtet med hujende tilråb og klapsalver.

Flere andre blev udnævnt som ambassadører for deres favoritart, og da arrangementet var omme, havde København fået en ambassadør for mursejler, pileborer, skovfirben, rotte, havtorn, hvepseedderkop, ægbladet fliglæbe, vintergæk og ræv. Til stede var venner til ambassadørerne samt aktive i Amager Fælleds Venner, et borgerinitiativ mod Københavns Kommunes planer om nye bebyggelser på Amager Fælled i København. De arbejder for at få området (gen)fredet for at beskytte biotopens artsmangfoldighed.

Flere antropologiske feltarbejdere var mødt op tiltrukket af blandingen mellem ambassadens politiske vision om at „gøre op med det artsegocentriske verdensbillede", som invitationen sagde, og ambassadørernes konkrete kærlighedserklæringer til andre arter, måske ubetydelige væsener for mange, men for dem afgørende. Det er en poetisk og politisk spænding, der for antropologer er i familie med fagfællers analyser af menneskets relationer med omverdenen i det antropocæne: om kunsten at bebo en skadet planet i kapitalismens ruiner ${ }^{2}$ for eksempel, og om at vi skal ned på jorden ${ }^{3}$ for at genfinde og genskabe bæredygtige relationer i klodens mangeartede politiske terræn.

Fænomenet artsambassadør stammer i Danmark fra initiativet Arternes Aarhus, som udnævner ambassadørerne og ifører dem ordensbånd med et emblem, der illustrerer deres art. Alt sammen til ambassadens åbning i København kunstfærdigt hjemmeklippet og malet af Frej og ambassadøren for ræv. ${ }^{4}$ Der var indkøbt naturvin og snacks, og fuglesang og fuglekvidder afspilledes på lydanlægget. Christiania TV's kamerafolk var til stede, og folk havde fint tøj på, flere af ambassadørerne var klædt ud som deres art. De tre ambassadører fra Aarhus var grøn klatrende vedbend, glitrende guldsmed og lyst lindetræ.

Nogle af ambassadørernes taler var anekdoter om deres politiske overbevisning. En ambassadør foruden Frej skrev et digt til sin art. Mursejlerambassadøren havde omskrevet et Steen Steensen Blicher-digt til at være en mursejlers sansning af byen. Den stigende tendens til at bygge huse med glatte glasbetonfacader gør det svært for den at bygge reder. Det er sådanne praktiske problemstillinger mellem mennesker og andre arter, man kan varetage som artsambassadør.

Men verden mellem Frej og stor vandsalamander rummer også mere. Når stor vandsalamander er en drage fra urtiden, og mennesket er unge aber, der i nutiden forplumrer verden, bliver stor vandsalamander et kernespørgsmål om, hvad menneskets natur er, og hvor den natur er på vej hen. Det er fra sin relation til salamanderen, at han taler til menneskeheden. 


\section{BioBlitz: Den politiske padde}

På en regnvåd søndag eftermiddag den 17. august 2019 i et krat på Amager Fælled i København hiver Frej fat $i$ et jordslået kludetæppe og fisker en stor vandsalamander frem. Han viser den til de fremmødte. De er mødt op til BioBlitz, hvor de i løbet af 24 timer skal registrere så mange arter som muligt på området for at dokumentere dets naturrigdom. BioBlitzen foregår på den del af Amager Fælled, hvor Københavns Kommune planlægger at bygge 5000 boliger - et område, som protestgruppen Amager Fælleds Venner har døbt Lærkesletten, fordi lærker yngler her, og som kommunen kalder Campinggrunden. ${ }^{5}$

Den store vandsalamander har en særlig betydning for Amager Fælleds Venners protest mod byggeriet. ${ }^{6}$ Det er en gullistet bilag 4-art i Bern-konventionen, fortæller Frej os i krattet, ${ }^{7}$ og det betyder, at ikke bare salamanderen, men også dens levesteder er fredede. Når Københavns Kommune vil „bygge krattet væk“, forklarer Frej, er det i strid med EU-lov, men eftersom det kun er ,gummiparagraffer", forstået på den måde at myndigheder næsten altid giver dispensation til at bøje konventionerne, når formelt set fredede områder skal bebygges, så taber naturen næsten altid til økonomien i retten. Kan den store vandsalamander bremse et byggeri, som skal medfinansiere den nye Metro-Cityring, det har taget Københavns Kommune næsten 10 år at bygge?

Stor vandsalamander har også en særlig betydning for en anden deltager, datalog og hobbypaddeekspert Henrik Bringsøe. Som aktiv i bjergsalamander.dk bruger han store dele af sin fritid på at dokumentere salamandere i den danske natur. Han fortæller om den store vandsalamanders sorte, næsten mørklilla, krop med dybgul bug med tilsvarende mørklilla pletter. Om eksemplaret $i$ sin hånd siger han, at den kun netop er kønsmoden og endnu uden de karakteristika, som kendetegner stor vandsalamander: den lange rygfinne, fire svømmefinner samt tyk hale. Henrik pakker salamanderen ind i plastikposen, fordi den kan udtørre ved berøring af mange, tørre hænder. Arten må formidles men ikke forstyrres. Salamanderen overdrages kortvarigt i plasticposen til en kunstfotograf, der vil tage et billede på hvid baggrund. ${ }^{8}$ 


\section{Interview: Dragesymbiosen}

I oktober 2019 møder vi Frej Schmedes i hans lejlighed på Islands Brygge. Lejligheden er i tre plan, og anordninger af papirbunker, filmgrej, kunst og tallerkenstakke og rekvisitter til aktivisme dækker alle flader. I et soveværelse har han et vægmaleri med planter, dyr og en flyvemaskine med Greenpeace-logo og contrails efter sig, på altanen et midlertidigt terrarie med rødmus, og der er vinduer ind til toilettet, fordi man ikke skal skamme sig over sin bare krop eller sin afføring. Der kan dog trækkes for. Vindeltrappen til lejlighedens øvrige etager leder mod flere liv og relikvier.

Frej kalder sit hjem for et sneglehus og fortæller, at han forbinder sin kærlighed til naturen med sin morfars stenhus og museum i Sydfrankrig. ${ }^{9}$ Her studerede morfar $\mathrm{Ib}^{10}$ insekter og padder i naturen, og en dag så Frej en ildsalamander, som nogle af morfarens besøgende med entusiasme og fascination havde fundet. Siden har han opsøgt stor vandsalamander i Nord- og Vestjylland, adskillige steder på Sjælland og nu på Amager Fælled.

Mit tilhørsforhold var ikke bare til landsbyen, min familie og mit land. Jeg har et tilhørsforhold til alle arter. Derfor vil jeg beskytte dem. Fordi jeg er i familie med dem. Fordi jeg kan mærke stamtræet. ${ }^{11}$ Når jeg ser en mus' rygrad, kan jeg mærke den i min rygrad.

Vi er i kamp om, hvilken form for natur i mennesket der skal dominere, og hvilken udvikling vi skal tage, og hvad vi skal satse på. Det er ikke kun en kamp om kultur.

Vi bliver nødt til at tage et meget unaturligt kvantespring, hvor vi skal udvikle os i symbiose med de andre arter frem for at forfine vores teknologi til at være bedre til at udnytte dem. Hele vores grundtanke, som menneske, er at forbedre egne vilkår og gøre det godt for de nærmeste. Nu bliver vi nødt til at udvide begrebet og forstå, at vores nærmeste er mange flere.

At være artsambassadør er et forsøg på at tage deres perspektiv og være deres stemme i det moderne demokrati. Hvad er det for noget med vores private ejendomsret? Hvor er den henne for ulven? Vi har taget det hele i vores artsegocentriske livssyn og sagt, at det er vores.

I Frankrig så jeg en ildsalamander, som en forsker havde taget hjem til min morfar. De er meget sjældne og bor oppe i nogle grotter og kræver nogle meget specielle forhold. Hele deres hellighed omkring det dyr! I forskerens og morfars opløftethed over og ydmyghed over at se dyret og passe på det og snakke om det, der kunne jeg mærke den samme hellighed, som man kan opleve i religiøsitet. Ildsalamanderen var ikke bare materie. Det var et væsen. Såre fantastisk og unikt og sjældent at opleve. Ildsalamanderen har kæmpestore gule streger og er ellers helt sort og glinsende. Det er et fortidsuhyre. Det er en af de gamle urdinosaurer, som stadigvæk er her. På en måde kan man sige, at dinosaurerne er blevet bittesmå. Dragerne er her endnu. De er fra dragernes tid. De er bare blevet vildt små. 
Der er et sted på Amager Fælled, hvor stor vandsalamander ligger i bunker i vinterhi, og jeg fortæller ikke nogen, hvor det er. Det er epicentret for deres overlevelse, og det er en skat. Da jeg fandt det en dag, blev jeg jo helt vild. Der var ikke kun store vandsalamandere, også snoge og små vandsalamandere og frøer. Alle sammen der på samme sted. Måske i en gammel forbrydelse. En, der har prøvet at grave nogle tyvekoster ned.

Den store vandsalamander, det er fortiden, fra før vi blev kristne, der er her stadigvæk. ${ }^{12}$ Lyslevende. Den ligner os, så vi kan forbinde os til en urtid og til en natur, som vi har brug for og sukker efter og har tabt forbindelsen til. Det er at spejle os i det vilde, som vi har mytologiske forhold til, fordi det er en drage. Drager kan flyve og spy ild. Det er vores urnatur. Den forbinder os til poesien og til eventyrene og til en naturmytologi, som er sand. Det er ikke løgn. Det er the real shit. Det rigtige eventyr det er her. Det er det. The real fairy tale with the dragon. Den bor herude.

Det er, fordi den er større og frækkere end den lille vandsalamander og tror mere på sig selv, at den er sårbar, fordi fiskehejrerne og fiskene og alle mulige andre kan se den i den åbne vandsøjle. Så det er jo et spørgsmål om levesteder og naturforarming. Den jager de større insekter i den åbne vandsøjle, hvor sigtbarhed spiller en rolle, så jo mere næringsforurening du har i vandhuller, jo færre vandhuller er der, hvor de kan klare sig. De små vandsalamandere klarer sig bedre der. Så det er simpelthen en art, der er på vej ud, fordi vi har for meget næring fra landbruget og fra afbrænding.

Vi har brug for at komme ud i det uregulerede. Vi har brug for at møde det vilde, som vi ikke styrer. Vi har brug for at møde det fremmede. Ellers bliver vi bange. Vi har brug for at være et lille menneske i den store natur, hvor vi bare er en lille art, en tosset abe med tøj på. Hvis vi bare er os selv med al vores teknologi, så misforstår vi, hvad vi er. Det er meget farligt og fattigt for os. Vildskaben er super vigtig som en balance for menneskets og for alle andre arters velbefindende.

Når du selv er i verden og ser omverdenen, så er du også med til at skabe omverdenen, fordi du er selv natur. Det bedste eksempel på det er jo regnbuen, for hvis der ikke er nogen, der ser regnbuen, så er den der ikke. Hvis der ikke er nogen synspunkter på regnbuen, så findes regnbuen simpelthen ikke. Den opstår i mødet mellem dit øje, dit synspunkt, og dit øje, husk det er natur, og så mødet mellem støv, som er mørke og rum, og energi, som er lys. Det vil sige, at du er medskaber af den æstetik, du oplever i omverdenen. Du er medskaber af omverdenen. Du kan slet ikke tage dig selv ud.

Vandsalamanderen sætter spørgsmål ved, om der er plads til det gamle. Om der er plads til det vilde. Om der er plads til fortiden. Om vi har råd til, at alt ikke skal være effektivt, og noget er besværligt og fylder og skal have ro. Eller om det hele skal være strømlinet og effektivt.

Vi er i kamp om, hvilken form for natur i mennesket der skal dominere, og hvilken udvikling vi skal tage, og hvad vi skal satse på. ${ }^{13}$ 


\section{Demonstration: Fælledens flerhed}

Den 9. december samles ${ }^{14}$ omkring 100 mennesker i det sene eftermiddagsmørke på fælleden tæt på stedet, hvor den store vandsalamander sover indtil april, måske før. De demonstrerer ${ }^{15}$ imod Københavns Kommunes beslutning om, at Fælledby skal bygges på Lærkesletten|Campinggrunden|byggefeltet|den store vandsalamanders hjem|Tornsangerland|metroens finansieringskilde.

Under sin vinterjakke bærer Frej roset og ordensbånd. Den storsovende salamander, vortet hud, orange mave, har livsprocesserne på standby, trækker vejret langsomt, tæt på, oppe i krattet i mudderet under en glemt klud eller i en mørnet træstamme beskyttet af kapitel 3 og bilag 4 .

En af Fælledbys bedømmere, en tidligere stadsarkitekt, karakteriserer byggefeltet som en vanskelig grund|en bar mark|dårligt nok et landskab|et sted, man kan gå amok som arkitekt. En af arkitekterne fra vinderfirmaet understreger, at de vil give stedet en identitet ${ }^{16} \mid$ bygge en by|gøre naturen rigere, ikke med det samme, men som den okkerfarvede streg på en planche viser, så vil naturværdien stige fra „ringe“ til ,god“ i Fælledby|et areal, som helt op til 1970'erne blev anvendt til losseplads|siden påfyldt med et lag ren jord som nulstillede områdets natur|en ruderatflora, som med tiden kan udvikle sig til et overdrev.

Efter kommunens og arkitektfirmaets præsentation spørger Frej, „hvordan kommunen og arkitektfirmaet har tænkt sig juridisk at forholde sig til, at den store vandsalamander er beskyttet strengere end pandaerne i Zoologiske Have". Han kan ikke forstå, „hvordan Lærkesletten kan kaldes for en ringe naturtype“, og hvordan man kan ,forøge biodiversiteten ved at bygge truede dyre- og plantearter væk. HVOR VOVER I PÅ VEGNE AF BIODIVERSITETEN, PA VEGNE AF DE VILDE ARTER?“. 


\section{Metamorfisk analyse}

Som et dragehoved på stævnen vil stor vandsalamander vogte sin skat med en bureaukratisk ild pustet til live af arternes ambassadører og fælledens venners protest mod byggeriet på Lærkesletten hvor dragens krop er gået i hi så dens lys må bæres af blussende fakler i en lysallé mod vandrehjemmet og langs alléen går Frej med megafon og giver den store vandsalamander en stemme og den trækker vejret langsomt sovende på ordensbåndet under hans vinterjakke sovende i det eventyrlige mudder under en klud eller i en mørnet træstamme den ved ikke at den $i$ dag skal jage midt $i$ vandsøjlen $i$ arkitekternes præsentationer og at Frej skal løsne paddernes stemmebånd og spy kritisk ild og vintersøvn over arkitekternes plantegninger de optegnede planer for Fælledby tegnet med de forkerte tuscher og de forkerte streger mens farveblyanterne blev lagt i en aflåst skuffe sammen med eventyrene og nøglen ligger netop et mudret sted under et kludetæppe og et sted hvor man kan tage ud og fare vild siger Frej det er ad de tilvoksede stier vi må gå de snor sig på Amager Fælled og her gennemgår stor vandsalamander et indviklet parringsspil få uger efter ankomsten til vandhullet æggene klækker bliver larver spiser dafnier bliver voksne går på land bliver drager flyver til vejrs i morgenrøden omgivet af fygende gnister fra brændet og vækker fra struben en søjle mellem urtid og demokrati denne kraft har altid været og vil altid være og uden mytologi intet kosmos uden skattevogter ingen helt uden stor vandsalamander ingen Frej mørklilla krop med dybgul bug og hvis salamanderen får lov ifølge EF-habitatdirektivet til at brede sine takker ud under den høje himmel over Fælleden vil vi se at vi er medskabere af omverdenen at vi er omverdenen at farverne opstår i mødet med øjet at modstanden og symbiosen opstår i mødet med de andre arter. 


\section{Noter}

Tak til Frej, Arternes Ambassade og studerende fra kurset „Antropologiske perspektiver pånaturopfattelser og naturetisk praksis“ efteråret 2019, som har bidraget til feltarbejde og analyse.

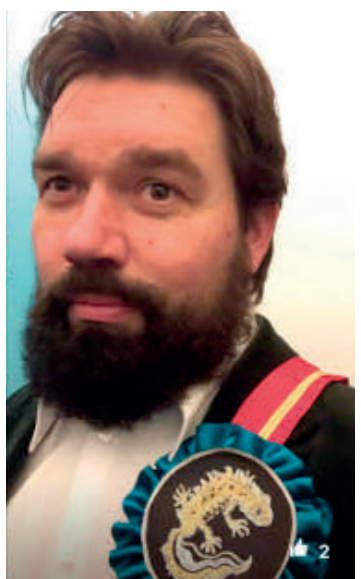

1.

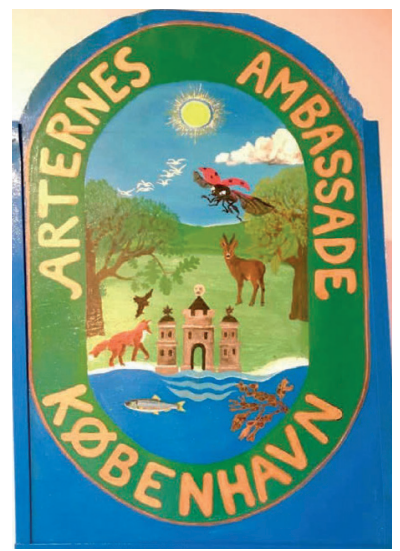

4.

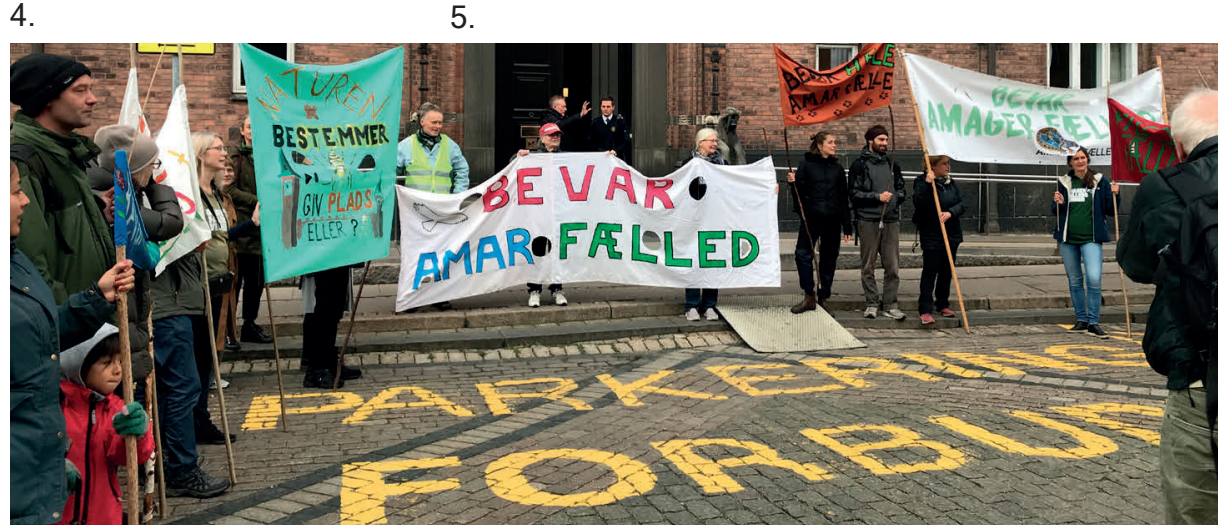

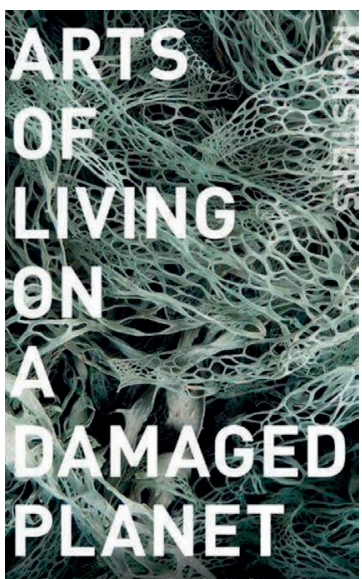

2.

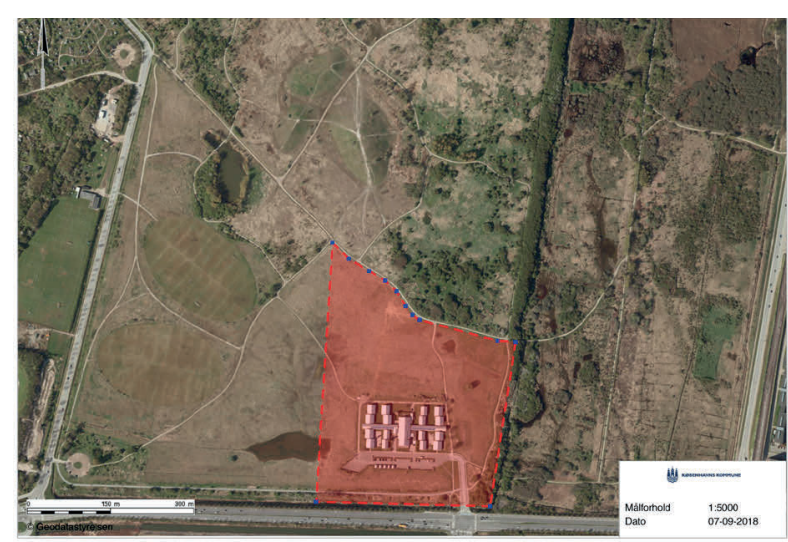

5.

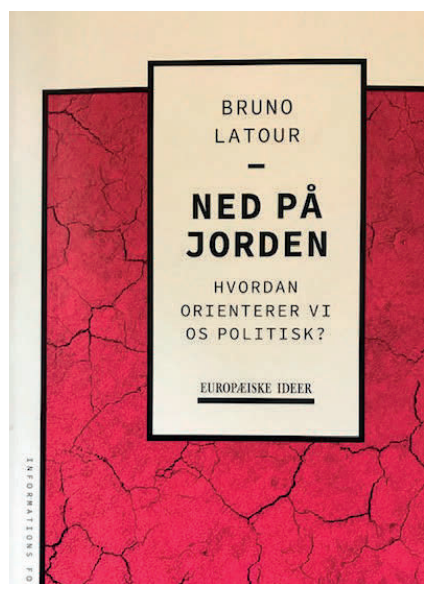

3.

NED PÅ

ORDEN

HVORDAN

ORIENTERER V

EUROPAISKE IDEER

6. 


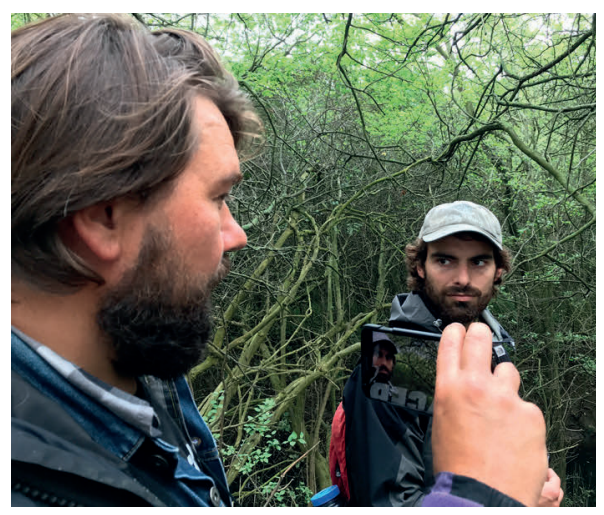

7.

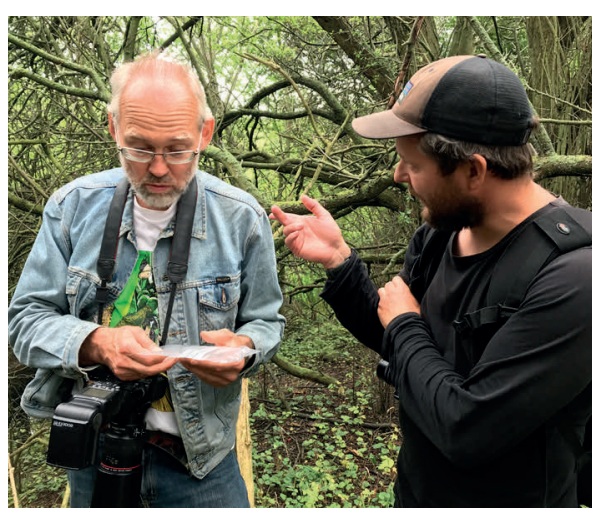

8.

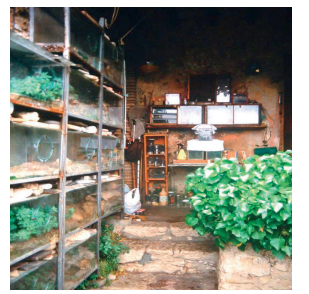

9. Foto: Lars Andersen.

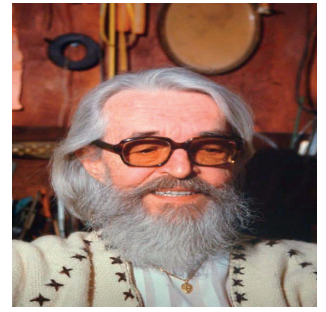

10. Foto: Lars Andersen.

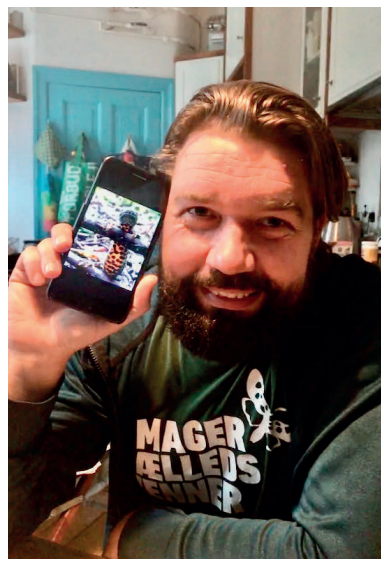

11. Foto: Lars Andersen.

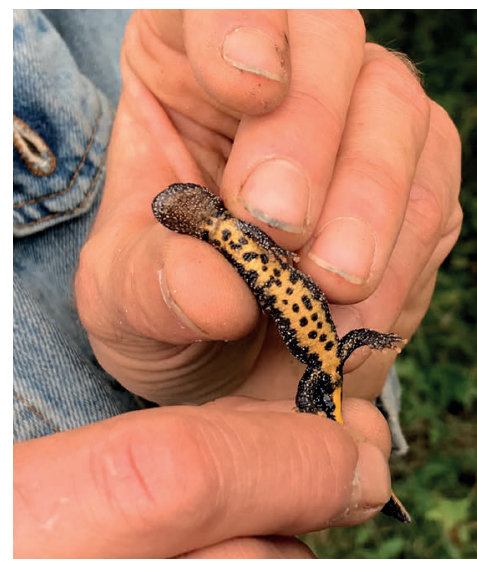

12.

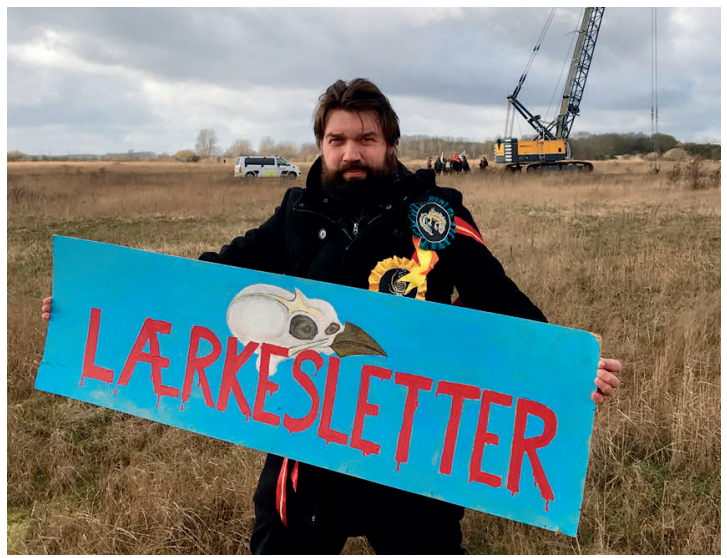

13. 


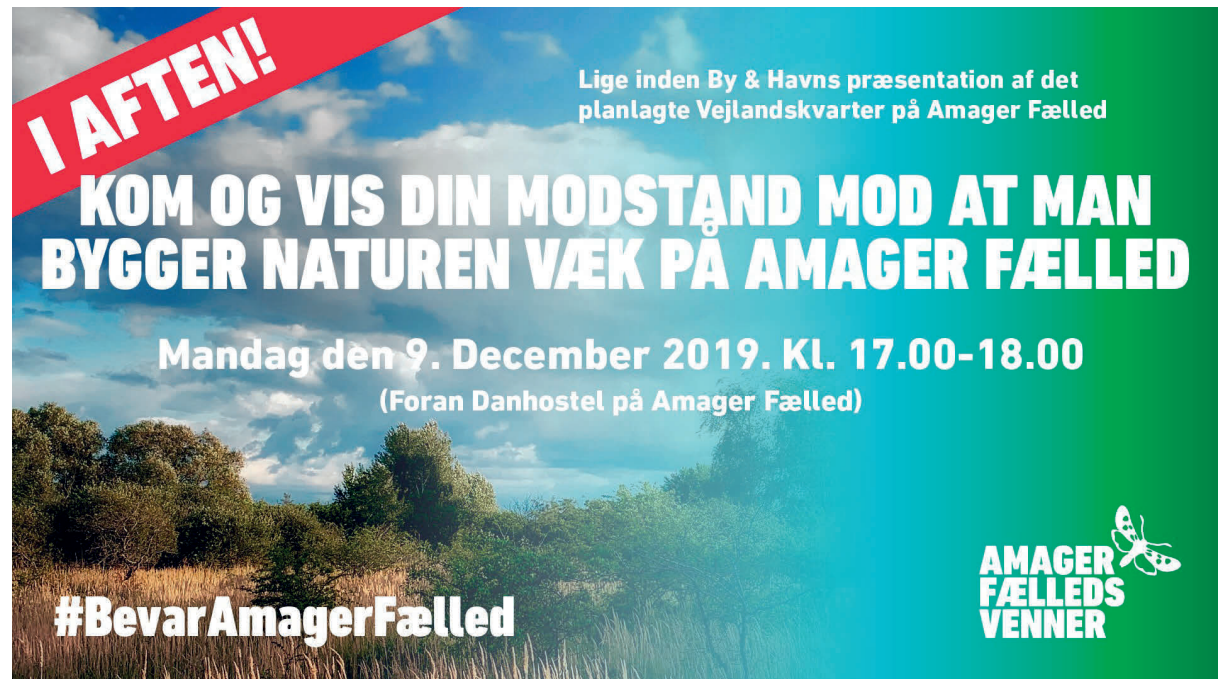

14.

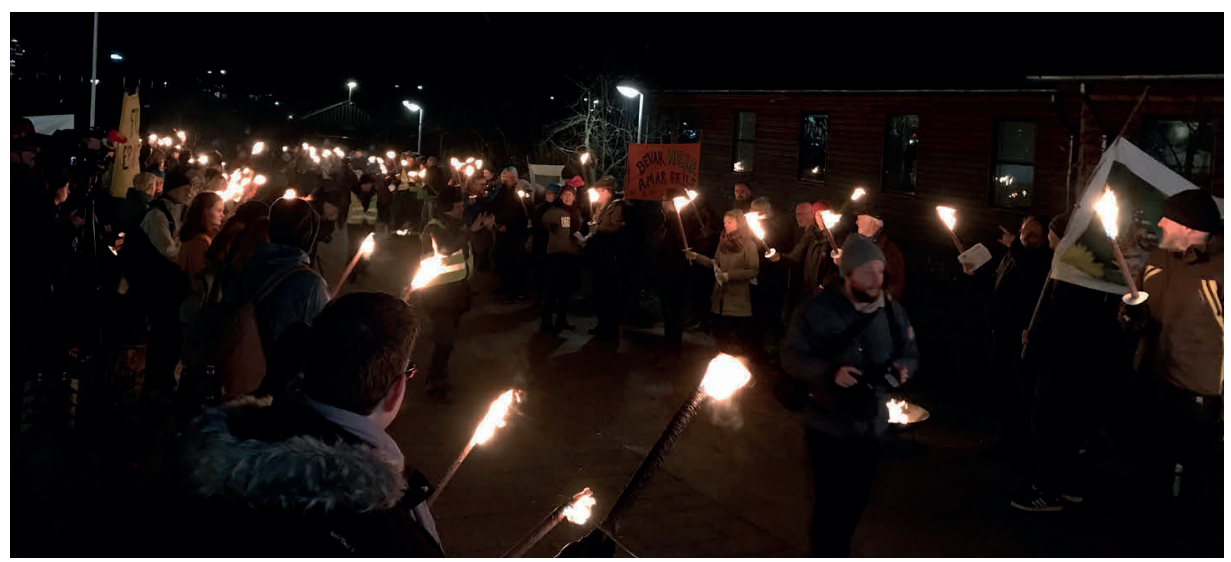

15.

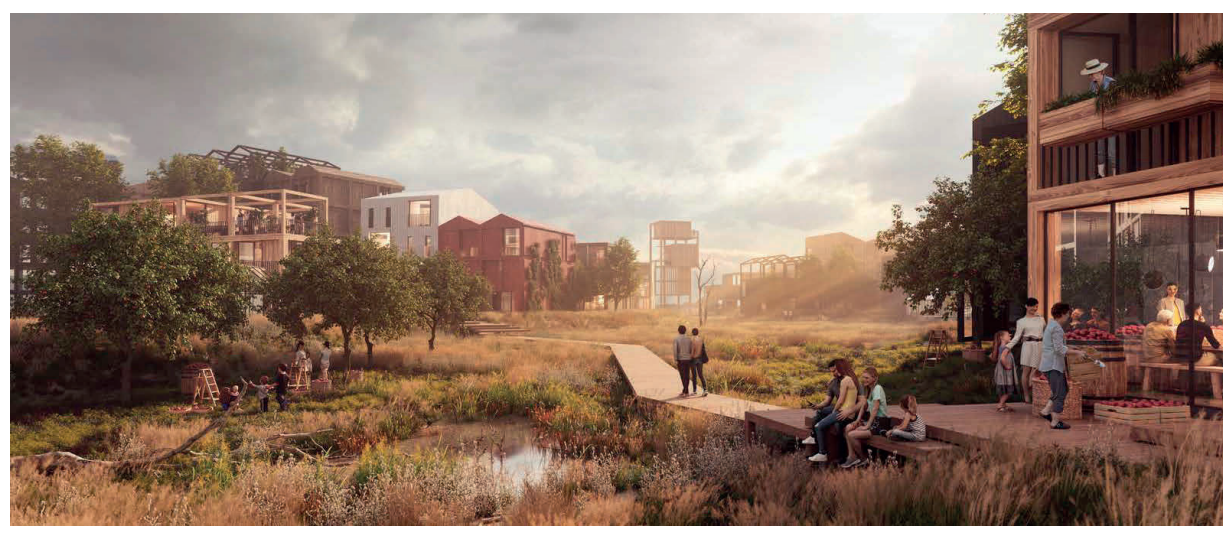

16. 